\title{
Influence Factors on the Properties of Ultrahigh-Performance Fiber-Reinforced Concrete Cured under the Condition of Room Temperature
}

\author{
Pu Zhang $\mathbb{D}^{1},{ }^{1}$ Yiliang Huang $\mathbb{D}^{2},{ }^{2}$ Yongqi $\mathrm{Li}^{2}{ }^{2}$ Jun Zhao, ${ }^{2}$ Hengqian Dong, ${ }^{2}$ and Tao Chen ${ }^{2}$ \\ ${ }^{1}$ School of Civil Engineering, Zhengzhou University, Zhengzhou 450001, China \\ ${ }^{2}$ Zhengzhou University, Zhengzhou 450001, China \\ Correspondence should be addressed to Pu Zhang; zhp1243@163.com
}

Received 2 February 2018; Accepted 24 April 2018; Published 11 July 2018

Academic Editor: Song Han

Copyright (c) $2018 \mathrm{Pu}$ Zhang et al. This is an open access article distributed under the Creative Commons Attribution License, which permits unrestricted use, distribution, and reproduction in any medium, provided the original work is properly cited.

Ultrahigh-performance fiber-reinforced concrete (UHPFRC) is a new type of concrete with excellent performance and good application prospects. However, expensive heat curing or high-pressure curing was often adopted to ensure the sufficient compressive strength. This study focuses on improving the compressive strength and workability of UHPFRC by changing the composition materials and the mixture ratios under standard curing conditions. The $0-1 \mathrm{~mm}$ and $1 \sim 3 \mathrm{~mm}$ sintered bauxite was adopted as coarse aggregate. UHPFRC with high compressive strength and good workability was developed by changing the water-binder ratios, by adding ground-granulated blast furnace slag (GGBFS) or fly ash, and by changing the bauxite content of different particle sizes. When the volume ratio of steel fiber was 3\%, the recommend water to binder ratio was 0.194 according to this experiment, the dosage of GGBFS-replaced cement is recommended as $20 \%$, the dosage of fly ash instead of silica fume is recommended as $30 \%$. The recommend ratio of $0-1 \mathrm{~mm}$ and $1 \sim 3 \mathrm{~mm}$ sintered bauxite was $1.51: 1$. Finally, a kind of UHPFRC material with a compressive strength of $152.4 \mathrm{MPa}$ and a slump of $120 \mathrm{~mm}$ was developed under the standard curing conditions.

\section{Introduction}

Ultrahigh-performance fiber-reinforced concrete [1] (UHPFRC) is a cement-based composite with superior mechanical properties. UHPFRC is often composed of fine particles of cement and ash-activated silica fume. In the process of condensation, hydration reaction and pozzolanic activity produce crystal and gel body. Fine aggregate, such as the crystals and the sintered bauxite, is the elastic skeleton, which results in elastic deformation; while the gel produces plastic deformation. UHPFRC has excellent mechanical properties, including high compressive strength, good bending resistance, excellent toughness, superior fatigue resistance, and high impact resistance. In addition, the internal porosity is often very compact in UHPFRC, thus resulting in a much better durability than that in normal concrete.

Silica fume (SF) is a material with a large specific surface area and high pozzolanic activity. The typical diameter of SF is about $0.2 \mu \mathrm{m}$; therefore, it is able to fill the pores between cement particles, while generating gel with hydration products. When UHPFRC was mixed with SF materials, their tiny spherical body can play a role in lubrication. Shi et al. [2] pointed out that the fluidity of UHSC increases along with the dosage of SF. However, when the SF content keeps increasing after its ratio reaches $15 \%-20 \%$, the fluidity of UHSC declines instead. Due to the lubricating effect of SF, the embedding water between small particles can be released, so when the SF content does not exceed $20 \%$, the fluidity of the mixture can be improved. When the content of SF exceeds $20 \%$, the surface area will be too large and it will reduce the liquidity. Richard and Cheyrezy [3] proposed that the optimal content of SF is about $25 \%$ of cement content, and Chan and Chu [4] thought that the optimum content of SF is $20 \%-30 \%$. Overall, if SF is too little, it results in a rapid formation of hydration products and forms a porous structure; therefore, the optimal dosage of SF in UHPFRC 
material should be above $20 \%$. SF can result pozzolanic activity and can increase the bulk density of the particles so as to densify the cement matrix and develop higher strength $[4,5]$. The improvement mechanism of SF to the pore structure is as follows: first, the gap among cement particles is filled by SF. Second, the existence of large amounts of C-S$\mathrm{H}$ gel, which is formed due to its volcanic ash reaction with calcium hydroxide, further reduces the pore size and capillary porosity during the hydration reaction $[6,7]$. Zhang and Han [8] pointed out that silica fume will also affect the fluidity of fresh concrete.

The amount of cement in UHPFRC is generally above $1000 \mathrm{~kg} / \mathrm{m}^{3}$, which is a large amount. The abuse of cement not only influences the cost but also has a negative impact on hydration heat and can cause shrinkage of concrete. Therefore, it is often common to add mineral admixtures into UHPFRC to replace cement to solve these problems. Wang and Zhi [9] found that the heat of cement hydration was reduced with the replacement of the auxiliary cementitious material. Several studies [2, 10-12] pointed out that the use of binary SF-FA (fly ash), SF-GGBFS (ground-granulated blast furnace slag), or ternary SF-GGBFS-FA binder systems not only reduces the content of SF but also has a positive effect on the mechanical properties. Yazici et al. [13] used GGBFS to replace cement in the production of RPC (reactive powder concrete) while adopted bauxite and granite as aggregate. The results showed that when the amount of cement replaced by GGBFS increases, the heat of hydration and shrinkage and the SF content can be reduced. This modification greatly reduced the demand for the superplasticizer. In addition, increasing mineral admixtures can increase the fluidity. Studies [14-16] showed that BFS (blast furnace slag) and FA can increase the fluidity under fresh conditions and densify the microstructure and can get higher strength due to its potential hydraulic and volcanic ash reactions. In addition, GGBFS reduces the porosity of concrete. Song and Saraswathy [17] pointed out that GGBFS can reduce the porosity, and the mineralogical changes of cement hydrate will lead to the decrease of chloride ion mobility.

Sintered bauxite is the most important aluminumbearing mineral, the main components are $\mathrm{Al}(\mathrm{OH})_{3}$, $\gamma$ - $\mathrm{AlO}(\mathrm{OH})$ and $\alpha-\mathrm{AlO}(\mathrm{OH})$, goethite, hematite, kaolinite, and a small amount of anatase $\mathrm{TiO}_{2}$. The density of natural sintered bauxite is $3.9-4 \mathrm{~g} / \mathrm{cm}^{3}$, and the hardness is among $1 \sim 3$. Because it is opaque and brittle, it will not be suitable as mortar or concrete aggregate. However, the strength and hardness of sintered bauxite far exceed most of the natural rock. Therefore, it is commonly used in ultrahigh strength and high wear-resistant mortar. Richard and Cheyrezy $[3,18]$ suggested that coarse aggregates should be removed to improve uniformity. However, Yazici et al. [13] studied the use of sintered bauxite and granite as aggregate in RPC; the largest aggregate size in the RPC mixture is $3 \mathrm{~mm}$, and the aggregate of $80 \%$ of the total mixture is used as the coarse aggregate $(1 \sim 3 \mathrm{~mm})$. Compared to conventional RPC (all aggregates which are in the form of powder $(<0.1 \mathrm{~mm})$ ), a good improvement was obtained, and it was demonstrated that bauxite aggregates have higher mechanical properties than the granite series. Yigiter et al. [19] also proved this conclusion. Zhang et al. [16] compared the effect of sintering bauxite, quartz sand, and black silicon carbide concrete in UHPFRC, and results showed that with sintered bauxite, aggregate can get higher compressive strength and resistance. Yazici et al. [13] and Yigiter et al. [19] explored the effect of sintered bauxite on UHPFRC performance by using sintered bauxite as the aggregate of RPC in the experiment and proved that bauxite can effectively improve its strength. However, the experiment did not discuss the impact of different sizes of sintered bauxite on the performance of UHPFRC.

Heat curing and autoclave curing can shorten the curing time, making the second hydration reaction between silica fume and the initial hydration product (calcium hydroxide), and give full play to the pozzolanic activity of silica fume and crushed quartz. Numerous studies have shown that [20-24], heat curing and autoclave curing can improve concrete strength compared to standard curing. Richard and Cheyrez [3] formulated RPC with a strength of up to $800 \mathrm{MPa}$ with steel fibers ( $10 \%$ by volume) and steel aggregate at temperatures up to $400^{\circ} \mathrm{C}$ and pressures of $50 \mathrm{MPa}$. In order to have high enough strength, heat curing or autoclave curing was usually required for UHPFRC. However, these curing measures are often high cost and difficult to apply, which greatly limit the engineering applications of UHPFRC. Therefore, many scholars have conducted researches on UHPFRC under standard curing conditions. Yazici et al. [13] and Yigiter et al. [19] using bauxite as the aggregate, formulated RPC and LCRPC with a compressive strength of more than $150 \mathrm{MPa}$ under standard curing conditions. It shows that satisfactory mechanical strength values can be obtained even in standard water curing. Arel [25] studied the influence of fineness and fiber aspect ratio of UHPFRC on compressive strength and impact resistance of UHPFRC under standard curing conditions, steam curing, and hot water curing conditions, respectively, and obtained UHPFRC with 28-day compressive strength of more than $150 \mathrm{MPa}$ under standard curing conditions. Wille et al. [26] obtained UHPFRC with compressive strength above $190 \mathrm{MPa}$ and a tensile strength up to $37 \mathrm{MPa}$ under the room temperature and atmospheric pressure.

Although some scholars have conducted research under standard curing conditions and have obtained satisfactory mechanical properties, UHPFRC from these studies still has the shortcomings of poor workability. Yazici et al. [13] and Yigiter et al. [19] formulated the concrete with a compressive strength of more than $150 \mathrm{MPa}$ under standard curing conditions. However, due to its low water-gel content and high SF content, the viscosity of the mixture is so great that it cannot be compacted except by using mechanical vibrations.

Based on the current research status, this project aims to obtain UHPFRC with both good workability and high compressive strength under the standard curing conditions, by conducting a series of experimental studies. This paper studied the effect of $\mathrm{W} / \mathrm{B}$ ratio, GGBFS ratio, $\mathrm{FA}$ ratio, aggregate particle size on the workability, and compressive strength of UHPFRC under standard curing conditions. Sintered bauxite was used instead of fine aggregate and sand in UHPFRC. 

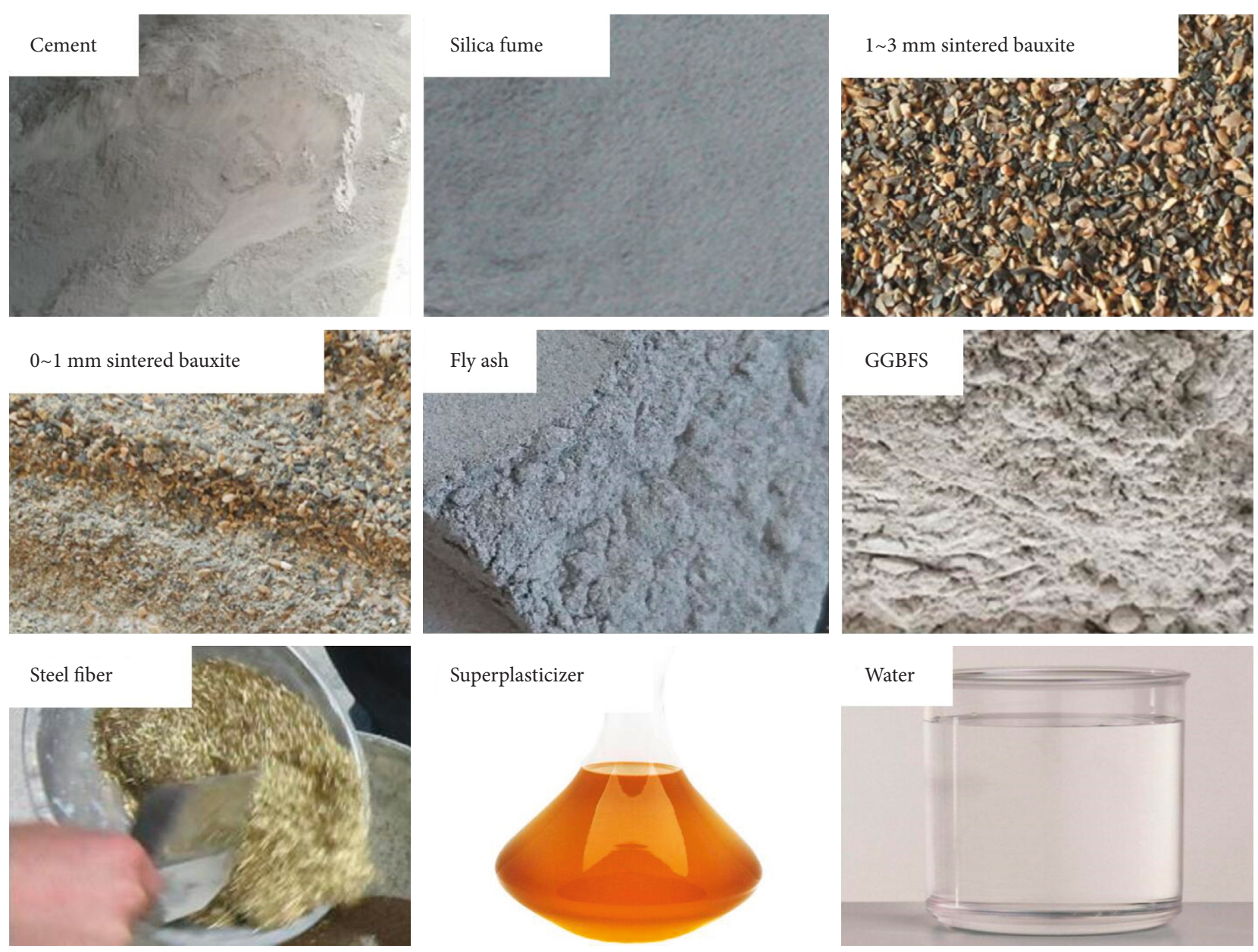

Figure 1: Composition materials of the UHPFRC.

\section{Experiment}

2.1. Materials. Ultrahigh-performance fiber-reinforced concrete (UHPFRC) is formulated by increasing the fineness and activity of the components and reducing the internal defects (voids and microcracks) of the material, and thus, the ultrahigh strength and durability is achieved. The composition materials (Figure 1) include the following:

(1) Cement: PO 52.5 ordinary Portland cement conforming to Chinese Standard GB 175-2007 [27].

(2) Sintered bauxite: sintered bauxite with particle sizes of $0-1 \mathrm{~mm}$ and $1 \sim 3 \mathrm{~mm}$. Sintered bauxite contains $71.8 \%$ of alumina the fire resistance $>1800^{\circ} \mathrm{C}$, density $3.9-4 \mathrm{~g} / \mathrm{cm}^{3}$, the hardness in the range of $1 \sim 3$, and crisp insoluble in water.

(3) GGBFS: S95 grade powder, whose fineness is about $430 \mathrm{~m}^{2} / \mathrm{kg}$, and the content ratio of moisture is smaller than $1.0 \%$.

(4) FA: use in line with the Chinese standard GB/T 15962005 [28] I-level fly ash.

(5) Polycarboxylate liquid superplasticizer: $40 \%$ solids, $35 \%$ water reduction, and $2 \mathrm{~h}$ no slump loss.

(6) Flat copper-plated steel fiber: the size of single steel fiber is $0.22 \mathrm{~mm} \times 13 \mathrm{~mm}$, with a tensile strength higher than $2850 \mathrm{MPa}$. The volume ratio of steel fiber was $3 \%$ for all specimens.

(7) SF: silica content is more than $95 \%$, with a density of $300 \mathrm{~kg} / \mathrm{m}^{3}$; specific surface area is $15 \sim 27 \mathrm{~m}^{2} / \mathrm{g} ; 28 \mathrm{~d}$ activity index is higher than $94 \%$; and the particle size is less than $1 \mu \mathrm{m}$, with the average particle size of $0.1 \mu \mathrm{m}$.

2.2. The Mix Proportion of Control Specimen. Yazici et al. [13] used sintered bauxite to develop UHPFRC with a compressive strength of more than $150 \mathrm{MPa}$ under standard curing conditions. However, the flowability of UHPFRC was poor when using the same mixing ratio with them, which is shown in Table 1. To solve the problem of the poor flowability of UHPFRC, a series of experimental study was done by changing the relative content of the original materials, and new materials were added to develop a kind of UHPFRC material with both high compressive strength and excellent workability. The mixing ratio listed in Table 1 was chosen as the control group of specimens.

2.3. Composition of the Mixtures. The composition of UHPFRC is shown in Tables 2 and 3. According to the different targets, the experiment was divided into five series: 
TABLE 1: The mix proportion of the control specimen $\left(\mathrm{kg} / \mathrm{m}^{3}\right)$.

\begin{tabular}{lcccccccccc}
\hline \multirow{2}{*}{ Number } & \multicolumn{3}{c}{ Powder } & & 0-1 mm bauxite & $1 \sim 3 \mathrm{~mm}$ bauxite & Steel fiber & SP L/m ${ }^{3}$ & Water & Water/binder \\
& Cement & GGBFS & FA & SF & & & & & & \\
\hline A0 & 940 & - & - & 282 & 240 & 940 & 234 & 55 & 125 & 0.1 \\
\hline
\end{tabular}

(1) Series A studied the influence of the $\mathrm{W} / \mathrm{B}$ ratio on the compressive strength and fluidity of UHPFRC. According to the different $\mathrm{W} / \mathrm{B}$ ratios, the specimens were divided into A1, A2, A3, A4, and A5, and the $\mathrm{W} / \mathrm{B}$ ratios were $0.164,0.174,0.184,0.194$, and 0.204 .

(2) Series B studied the influence of the ratio of GGBFS substituting the cement content on the compressive strength and fluidity of UHPFRC. According to the different amount of GGBFS, the specimens were divided into B1, B2, and B3, and the GGBFS content was $10 \%, 20 \%$, and $30 \%$ of the cement.

(3) Series $C$ studied the influence of the $W / B$ ratio on the compressive strength and fluidity of UHPFRC with 20\% GGBFS content. According to the different W/B ratio, the specimens were divided into $\mathrm{C} 1, \mathrm{C} 2$, and $\mathrm{C} 3$, and the W/B ratios were 0.174, 0.184, and 0.194.

(4) Series D studied the influence of FA-replaced partial SF on compressive strength and fluidity of UHPFRC. According to the dosage of FA replacing SF, the specimens were divided into D1, D2, and D3, and the amounts of replacement ratio were $10 \%, 20 \%$, and $30 \%$.

(5) Series E studied the influence of the amount of different particle sizes of sintered bauxite on the compressive strength and fluidity of UHPFRC. According to the different proportions of bauxite with different particle sizes, the specimens were divided into E1 and E2, and the proportions of 0 - $1 \mathrm{~mm}$ bauxite and $1 \sim 3 \mathrm{~mm}$ bauxite were $0.755: 0.5$ and $1.255: 0$.

2.4. Specimen Preparation and Curing. Materials are added to the stirring pot in the order of $1 \sim 3 \mathrm{~mm}$ of sintered bauxite, $0-1 \mathrm{~mm}$ of sintered bauxite, cement, silicon powder, and GGBFS. Water was added into the mixing pot to join all after dry mixing for 1 minute, and then mixing was continued for about 2 minutes. Then the superplasticizer was added and continuously stirred for 5 minutes. Finally, steel fiber was added and was stirred for 2 minutes. Then the mixture was compacted by vibration and then was cured for 28 days under the standard condition (temperature: $20 \pm 2{ }^{\circ} \mathrm{C}$, humidity: $\geq 95 \%$ ) after the specimens were taken out of the molds. The compression test specimen is a cube of $100 \mathrm{~mm} \times 100 \mathrm{~mm} \times 100 \mathrm{~mm}$. Photos of specimens' preparation are shown in Figure 2.

2.5. Test Method. The test mainly focused on the fluidity and the compressive strength of the UHPFRC. The compressive strength test was conducted according to the test method specified in "GB/T 31387-2015 Reactive Powder Concrete"
TABLE 2: Composition of the mixtures and the test results.

\begin{tabular}{lccccc}
\hline Material $\left(\mathrm{kg} / \mathrm{m}^{3}\right)$ & A1 & A2 & A3 & A4 & A5 \\
\hline Cement & 940 & 940 & 940 & 940 & 940 \\
GGBFS & - & - & - & - & - \\
FA & - & - & - & - & - \\
SF & 282 & 282 & 282 & 282 & 282 \\
$0-1 \mathrm{~mm}$ bauxite & 240 & 240 & 240 & 240 & 240 \\
1 3 mm bauxite & 940 & 940 & 940 & 940 & 940 \\
Steel fiber & 234 & 234 & 234 & 234 & 234 \\
SP $\left(\mathrm{L} / \mathrm{m}^{3}\right)$ & 70.5 & 70.5 & 70.5 & 70.5 & 70.5 \\
Water & 200 & 212 & 225 & 237 & 250 \\
Water/binder & 0.164 & 0.174 & 0.184 & 0.194 & 0.204 \\
Compressive strength $(\mathrm{MPa})$ & & & & & \\
7 days & 128 & 130.5 & 115.5 & 110.6 & 120.5 \\
28 days & 149.7 & 150.5 & 145.7 & 146.5 & 141.3 \\
Slump (cm) & 0 & 3.9 & 5 & 8.5 & 10.1 \\
\hline
\end{tabular}

[29]. The loading speed is $1.2 \sim 1.4 \mathrm{MPa} / \mathrm{s}$. The slump test of the mixture was conducted according to the test method specified in GB/T 50080-2016 [30]. Three specimens were tested for each batch to eliminate the discreteness of the test.

\section{Results and Discussion}

3.1. Influence of $W / B$ Ratio on the Compressive Strength and Fluidity of UHPFRC (Series A). Influence of the W/B ratio on the compressive strength and fluidity of UHPFRC is shown in Figure 3. As shown in Figure 3, the compressive strength of UHPFRC decreases with the increase of the $W / B$ ratio. Specifically, while the W/B ratio was changed in the range of 0.164-0.204, the compressive strength reached a peak of $150.5 \mathrm{MPa}$ when the $\mathrm{W} / \mathrm{B}$ ratio was 0.174 ; and the compressive strength reduced to $141.3 \mathrm{MPa}$ when the $\mathrm{W} / \mathrm{B}$ ratio was 0.204; the compressive strength when the $\mathrm{W} / \mathrm{B}$ was equal to 0.184 is lower than the compressive strength when the $\mathrm{W} / \mathrm{B}$ ratio was equal to 0.194 . The reason is that when the value of the $\mathrm{W} / \mathrm{B}$ ratio is reduced, the viscosity of fresh concrete increases, resulting in difficulty to vibrate and compact, resulting relatively large bubbles and microcracks within the test block, thus reducing the compressive strength.

As can be seen from Figure 4, when the W/B ratio is 0.164 , the fluidity of fresh concrete was very poor, unable to measure its slump, and no liquidity was observed. When the $\mathrm{W} / \mathrm{B}$ ratio was in the range of $0.174 \sim 0.184$, the fresh concrete had moderate fluidity, and its surface can become flat when vibrating densely; however, the time required was a little longer. When the $\mathrm{W} / \mathrm{B}$ ratio is in the range of $0.194 \sim 0.204$, the fresh concrete had excellent fluidity, its surface can become flat fast when vibrating and the time required for final vibration compacting was much less. The fluidity of UHPFRC increases with the increase of the $\mathrm{W} / \mathrm{B}$ ratio, which 
TABLE 3: Composition of the mixtures and the test results.

\begin{tabular}{|c|c|c|c|c|c|c|c|c|c|c|c|}
\hline Material $\left(\mathrm{kg} / \mathrm{m}^{3}\right)$ & B1 & $\mathrm{B} 2$ & B3 & $\mathrm{C} 1$ & $\mathrm{C} 2$ & $\mathrm{C} 3$ & D1 & D2 & D3 & E1 & E2 \\
\hline Cement & 846 & 752 & 658 & 752 & 752 & 752 & 940 & 940 & 940 & 940 & 940 \\
\hline GGBFS & 94 & 188 & 282 & 188 & 188 & 188 & - & - & - & - & - \\
\hline FA & - & - & - & - & - & - & 28.2 & 56.4 & 84.6 & - & - \\
\hline SF & 282 & 282 & 282 & 282 & 282 & 282 & 253.8 & 225.6 & 197.4 & 282 & 282 \\
\hline $0-1 \mathrm{~mm}$ bauxite & 240 & 240 & 240 & 240 & 240 & 240 & 240 & 240 & 240 & 710 & 1180 \\
\hline $1 \sim 3 \mathrm{~mm}$ bauxite & 940 & 940 & 940 & 940 & 940 & 940 & 940 & 940 & 940 & 470 & 0 \\
\hline Steel fiber & 234 & 234 & 234 & 234 & 234 & 234 & 234 & 234 & 234 & 234 & 234 \\
\hline $\mathrm{SP}\left(\mathrm{L} / \mathrm{m}^{3}\right)$ & 70.5 & 70.5 & 70.5 & 70.5 & 70.5 & 70.5 & 70.5 & 70.5 & 70.5 & 70.5 & 70.5 \\
\hline Water & 237 & 237 & 237 & 212 & 225 & 237 & 237 & 237 & 237 & 237 & 237 \\
\hline Water/binder & 0.194 & 0.194 & 0.194 & 0.174 & 0.184 & 0.194 & 0.194 & 0.194 & 0.194 & 0.194 & 0.194 \\
\hline \multicolumn{12}{|c|}{ Compressive strength (MPa) } \\
\hline 7 days & 106.2 & 105.3 & 89.6 & 106.5 & 108 & 105.3 & 119.2 & 106.5 & 115.2 & 115.7 & 121.2 \\
\hline 28 days & 141.4 & 140.1 & 121.5 & 132 & 131.7 & 140.1 & 144.6 & 137.6 & 148.6 & 152.4 & 155.5 \\
\hline Slump $(\mathrm{cm})$ & 9.2 & 10.1 & 12 & 2 & 3.5 & 10.1 & 9.6 & 7.2 & 14.1 & 12 & 7.3 \\
\hline
\end{tabular}

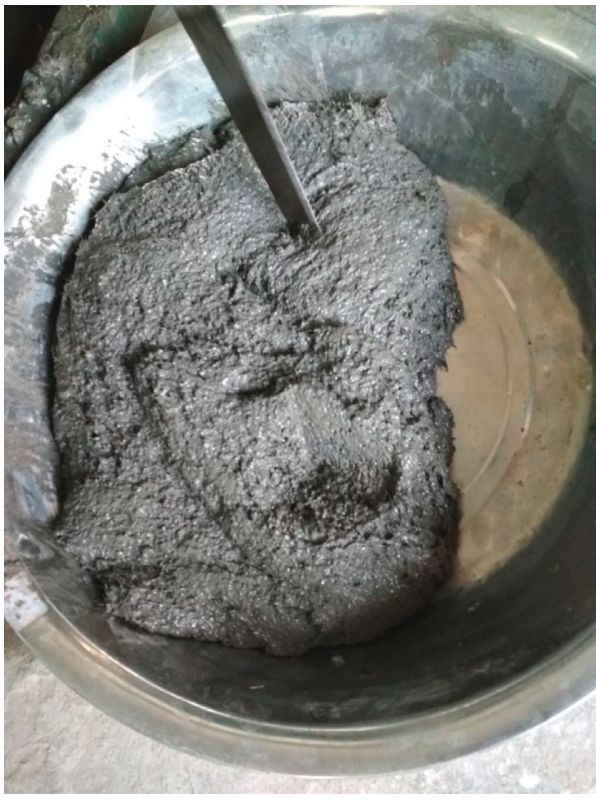

(a)

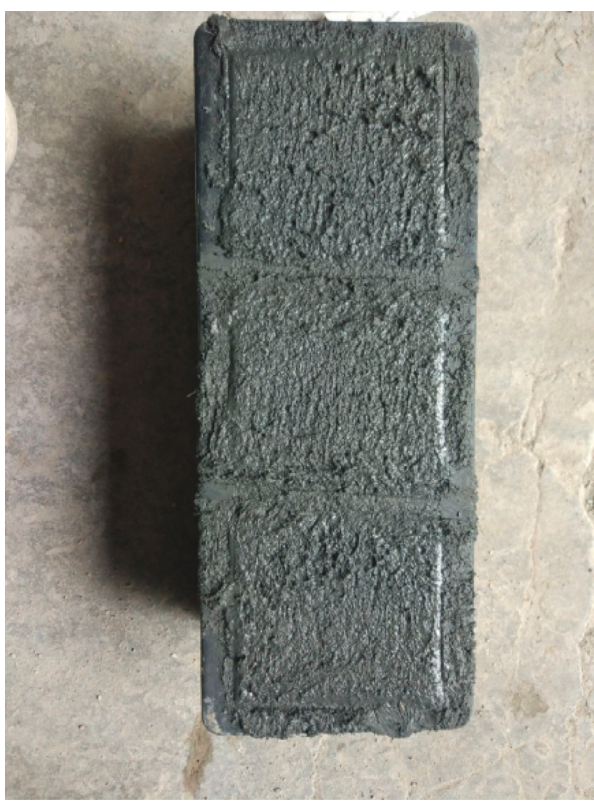

(b)

FIgURE 2: Photos of specimen preparation.

is because, in a certain range, the increase of the $\mathrm{W} / \mathrm{B}$ ratio will increase the amount of gel formation, thereby reducing the friction between the aggregates and improving the fluidity. Based on the UHPFRC compressive strength and the fluidity of the mixture, the optimum $\mathrm{W} / \mathrm{B}$ ratio is recommended as 0.194 according to this test.

3.2. Influence of the Content of GGBFS-Replaced Cement on the Compressive Strength and Fluidity of UHPFRC (Series B). To reduce the cost of UHPFRC, GGBFS powder was used instead of some of the amount of the cement. Addition of GGBFS is beneficial to delay the peak point of hydration heat, and it can reduce hydration heat and reduce the occurrence of temperature cracks. In order to explore the optimal content of GGBFS-replaced cement, the experiment

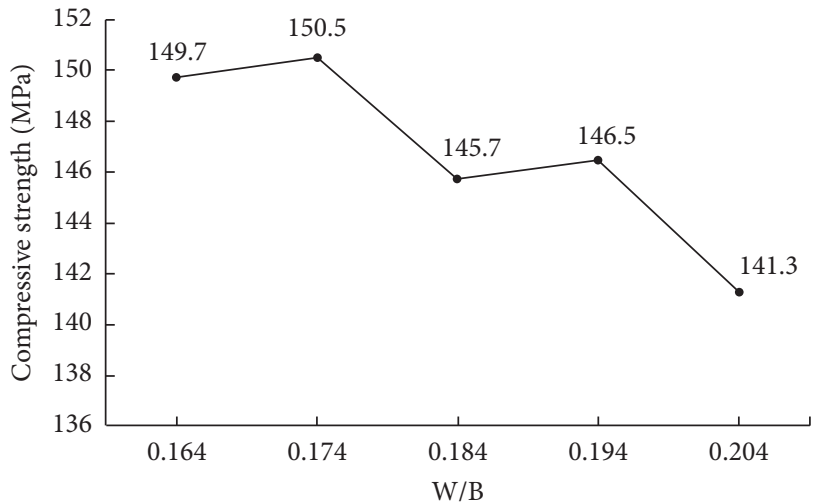

FIGURE 3: Influence of the W/B ratio on the compressive strength of UHPFRC. 


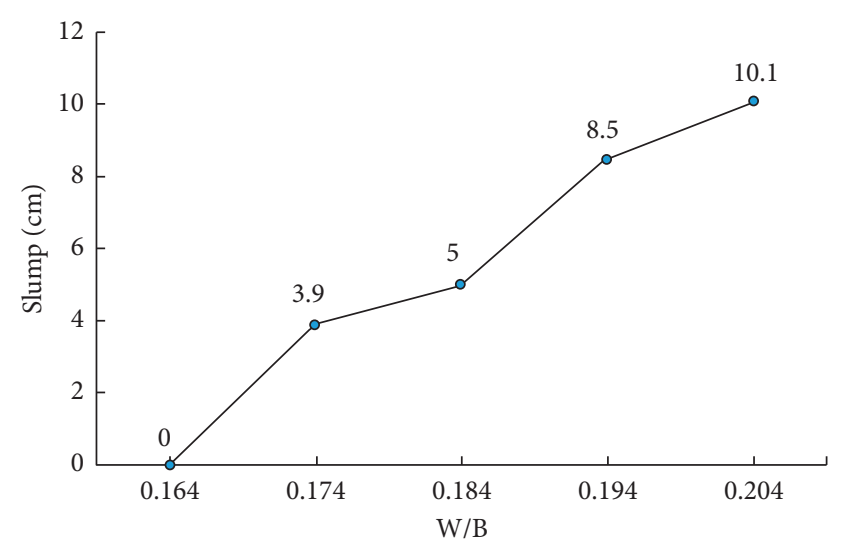

FIgURE 4: Influence of the W/B ratio on the slump of UHPFRC.

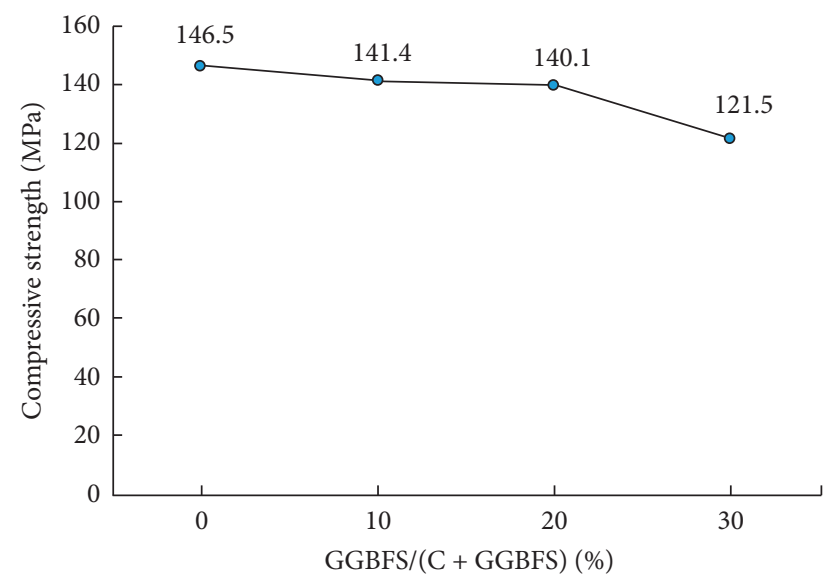

FIGURE 5: Influence of the content of GGBFS-replaced cement on the compressive strength of UHPFRC.

was carried out when kept the same total amount of cement and GGBFS $\left(940 \mathrm{~kg} / \mathrm{m}^{3}\right)$.

Influence of the content of GGBFS-substituted cement on the compressive strength of UHPFRC can be seen in Figure 5. The influence of the content of GGBFS-replaced cement on the slump of UHPFRC is shown in Figure 6. As is shown in the figure, with the increasing of the content of GGBFS-replaced cement, the fluidity of the mixture was gradually increased, and the workability of the mixture has been greatly improved. GGBFS powder can be filled in the cement particle gap and can form a flocculation structure, thus occupying the water-filled space, and then water is released from the original flocculation structure, and the slurry becomes thin. If the amount of water was kept the same, the workability and mobility of UHPFRC can be improved.

As can be seen from Figure 5, the compressive strength decreases with the increasing of the content of GGBFS instead of the cement. The specimen compressive strength decreased from $146.5 \mathrm{MPa}$ (content $0 \%$ ) to $121.5 \mathrm{MPa}$ (content 30\%), which decreased by $25 \mathrm{MPa}$. However, when the GGBFS content replaced $20 \%$ of the cement $\left(188 \mathrm{~kg} / \mathrm{m}^{3}\right)$, the compressive strength only reduces to $6.4 \mathrm{MPa}$, and its slump reaches $10.1 \mathrm{~cm}$. Based on the compressive strength of

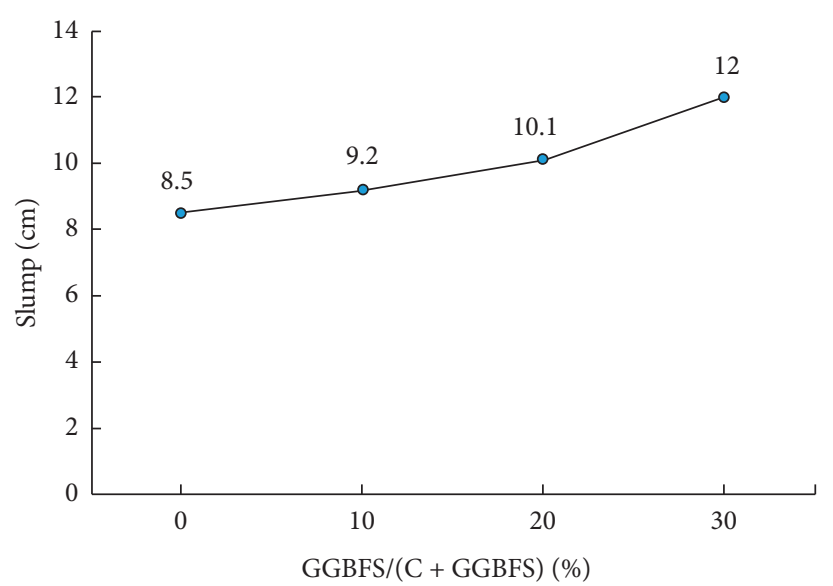

Figure 6: Influence of the content of GGBFS-replaced cement on the slump of UHPFRC.

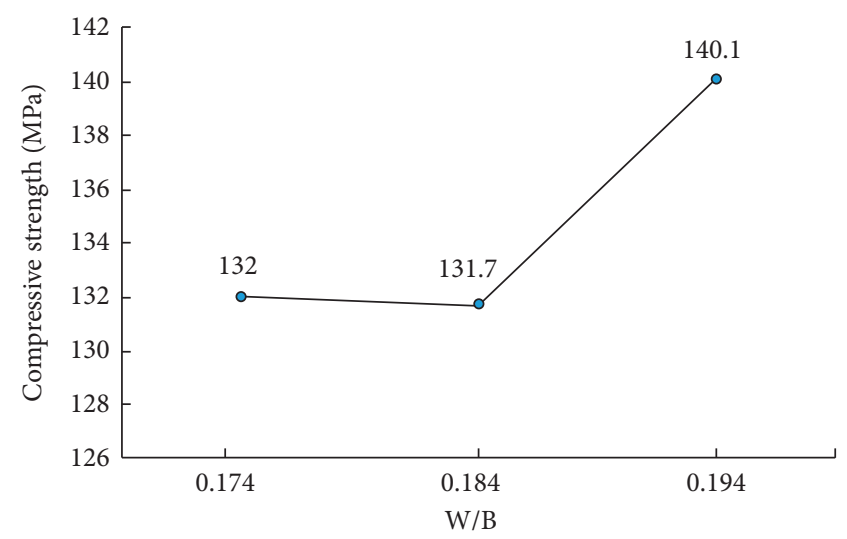

FIGURE 7: Influence of the W/B ratio on the compressive strength of UHPFRC when GGBFS replaced $20 \%$ of the cement.

UHPFRC and the fluidity of the mixture, the composite performance of UHPFRC is considered to be superior when the GGBFS content replaced $20 \%$ of the cement.

3.3. Influence of the W/B Ratio on the Compressive Strength and the Fluidity of UHPFRC When GGBFS Replaced 20\% of the Cement (Series C). According to the measured data, when the amount of GGBFS is replaced instead of $20 \%$ of the cement $\left(188 \mathrm{~kg} / \mathrm{m}^{3}\right)$, influence of the $\mathrm{W} / \mathrm{B}$ ratio on the compressive strength of UHPFRC is shown in Figure 7. Influence of the $\mathrm{W} / \mathrm{B}$ ratio on the fluidity of UHPFRC when GGBFS replaced $20 \%$ of the cement is shown in Figure 8.

It can be concluded from Figure 7 that the compressive strength increases with the increase of the $\mathrm{W} / \mathrm{B}$ ratio. The compressive strength was $140.1 \mathrm{MPa}$ when the $\mathrm{W} / \mathrm{B}$ ratio is equal to 0.194 , which is higher than those when the W/B ratios are equal to $0.174(132 \mathrm{MPa})$ and $0.184(131.7 \mathrm{MPa})$.

As can be seen from Figure 8, the slump increases when the $\mathrm{W} / \mathrm{B}$ ratio is increased. The slump $(10.1 \mathrm{~cm})$ of UHPFRC when the value of the W/B ratio was equal to 0.194 also increased greatly compared with the slump when the values of the $\mathrm{W} / \mathrm{B}$ ratios were equal to $0.174(2 \mathrm{~cm})$ and 0.184 $(3.5 \mathrm{~cm})$. The mixture was relatively viscous when the $\mathrm{W} / \mathrm{B}$ 


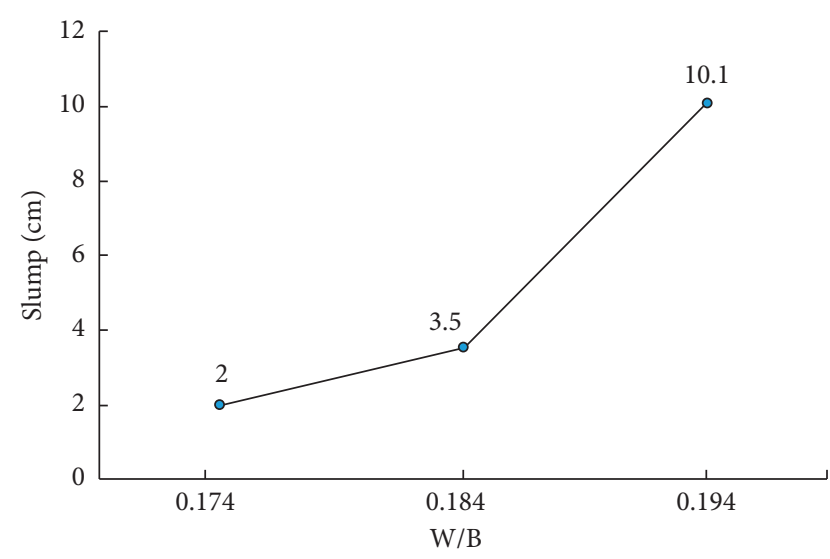

FIGURE 8: Influence of the W/B ratio on the fluidity of UHPFRC when GGBFS replaced $20 \%$ of the cement.

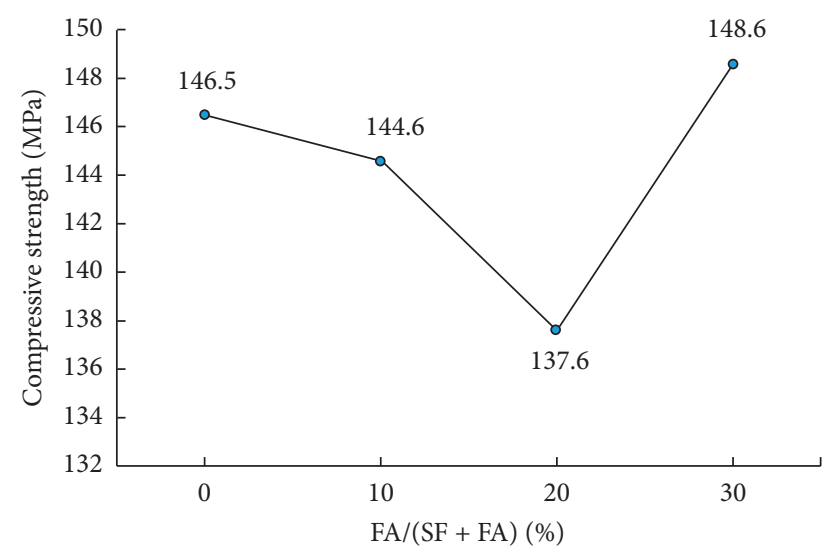

FIGURE 9: Influence of FA-replaced partial SF on the compressive strength of UHPFRC.

ratio was equal to 0.174 or 0.184 ; mechanical vibration was needed, and it was difficult to vibrate dense. However, the fluidity of the specimen with the $\mathrm{W} / \mathrm{B}$ ratio equal to 0.194 is much better, which can be vibrated compactly fast by mechanical vibrating. The result shows that the $\mathrm{W} / \mathrm{B}$ ratio has a great influence on the compressive strength and the slump of UHPFRC. Based on the compressive strength of the UHPFRC and the fluidity of the mixture, the overall performance of the UHPFRC is optimal when the $\mathrm{W} / \mathrm{B}$ ratio is 0.194 and when the GGBFS replaced $20 \%$ of the cement.

3.4. Influence of FA-Replaced Partial SF on Compressive Strength and Fluidity of UHPFRC (Series D). FA can have a positive impact on the mechanical properties of concrete when it was used to replace part of the SF in UHPFRC with an appropriate dosage. In order to determine the optimal amount of fly ash (FA)-replaced silica fume (SF), experiments with different $\mathrm{FA} / \mathrm{SF}$ ratios were carried out while keeping the total amount of silica fume and fly ash $\left(282 \mathrm{~kg} / \mathrm{m}^{3}\right)$ the same. According to the test results, the influence of the dosage of FA replacing SF on the compressive strength of UHPFRC is shown in Figure 9. The

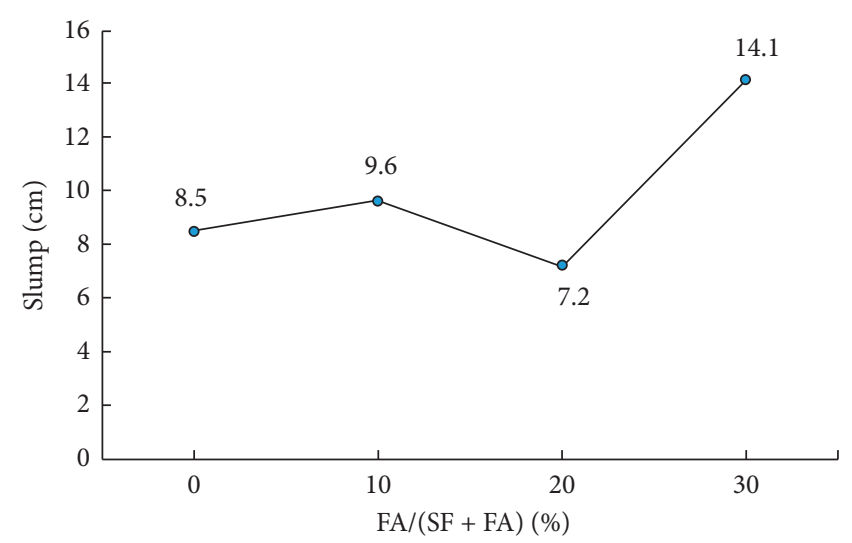

FIGURE 10: Influence of FA-replaced partial SF on fluidity of UHPFRC.

influence of FA-replaced SF on the slump of UHPFRC is shown in Figure 10.

As can be seen from Figure 9, the compressive strength of UHPFRC decreases first and then increases when the FA ratio is increased. The compressive strength was reduced from 146.5 $\mathrm{MPa}$ to $137.6 \mathrm{MPa}$ and then increased to $148.6 \mathrm{MPa}$. The compressive strength of the specimen with the FAreplaced SF ratio equal to $30 \%$ was slightly higher than that of no FA specimens. This is because the synergistic effect of SF and FA reaches a high level when FA replaced 30\% of SF. Adding SF can improve the compressive strength, while adding FA can improve the fluidity. As is shown in Figure 10, with the increase of the amount of FA replacing SF, the mixture gradually changed from viscous to semiviscous in the stirring process, which means the workability was improved gradually, and the overall trend of fluidity increases gradually. Considering the compressive strength and the fluidity of the UHPFRC, the comprehensive performance of the UHPFRC is optimal when the FA replaces the $\mathrm{SF}$ with $30 \%\left(84.6 \mathrm{~kg} / \mathrm{m}^{3}\right)$.

3.5. Influence of the Amount of Different Particle Sizes of Sintered Bauxite on Compressive Strength and Fluidity of UHPFRC (Series E). In this experiment, sintered bauxite of different particle sizes was used as aggregate. Influence of the size of sintered bauxite on the properties of UHPFRC was investigated by changing the amount of sintered bauxite with different particle sizes. The total amount of sintered bauxite constant was kept as a constant value while the mixing ratios of different particle sizes of bauxite were changing. According to the measured results, the influence of the amount of different sizes of bauxite on the compressive strength of UHPFRC is shown in Figure 11. The influence of the amount of different size of bauxite on the slump is shown in Figure 12.

As can be seen from Figures 11 and 12, the compressive strength and fluidity of the concrete vary greatly with different particle size ratios of sintered bauxite. With the increase of the ratio of $0-1 \mathrm{~mm}$ sintered bauxite to $1 \sim 3 \mathrm{~mm}$ sintered bauxite, the strength of the UHPFRC increased. When the ratio of $0-1 \mathrm{~mm}$ sintered bauxite to $1 \sim 3 \mathrm{~mm}$ 


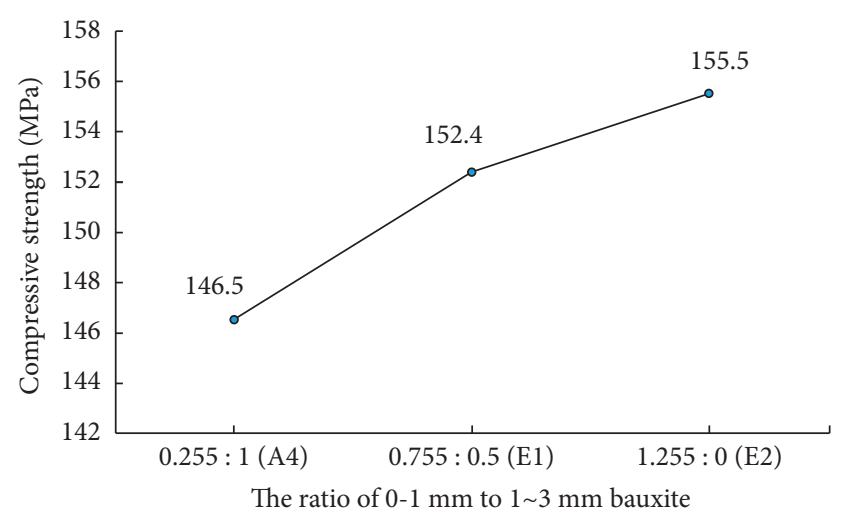

Figure 11: Influence of the amount of different particle sizes of sintered bauxite on the compressive strength of UHPFRC.

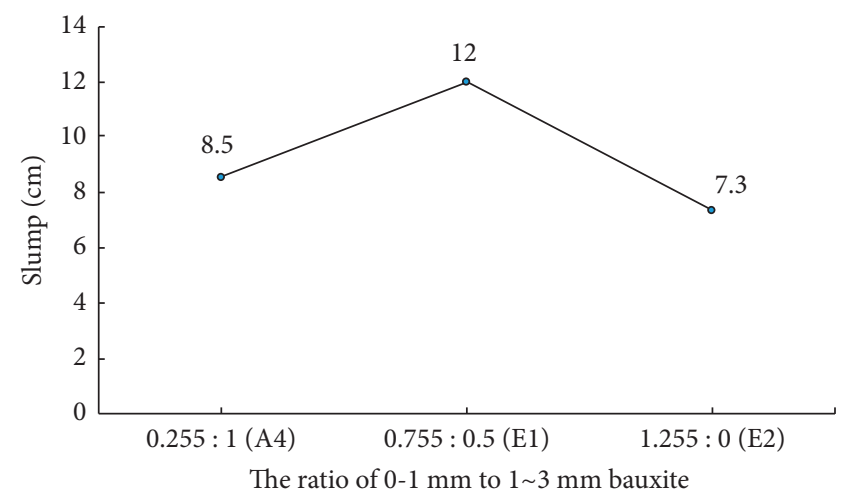

FIGURE 12: Influence of the amount of different particle sizes of sintered bauxite on the fluidity of UHPFRC.

sintered bauxite was $1.255: 0$, the strength of the concrete reached a maximum of $155.5 \mathrm{MPa}$. The fluidity was the best when the ratio of $0-1 \mathrm{~mm}$ sintered bauxite to $1 \sim 3 \mathrm{~mm}$ sintered bauxite was $0.755: 0.5(1.51: 1)$. The difference of strength between the two groups was not significant, while the slump of E1 was $12 \mathrm{~cm}$ which was significantly higher than that of E2. Therefore, the overall performance of the UHPFRC was optimal when the ratio of $0-1 \mathrm{~mm}$ sintered bauxite to $1 \sim 3 \mathrm{~mm}$ sintered bauxite was $1.51: 1$.

\section{Conclusions}

This study aims to solve the shortcomings of the poor current fluidity of UHPFRC (temperature: $20 \pm 2^{\circ} \mathrm{C}$, humidity: $\geq 95 \%$ ), by changing the relative content of the original materials and attempting to add new materials. UHPFRC with excellent mechanical properties and excellent workability was developed under the standard curing conditions, with the values of the compressive strength reaching 152.4 MPa and the slump reaching $12.0 \mathrm{~cm}$. Based on the test results, the influencing factors of UHPFRC strength and construction performance are analyzed in detail. The conclusions are as follows:

(1) UHPFRC with a compressive strength of more than $150 \mathrm{MPa}$ and excellent workability was developed under standard curing conditions.
(2) The W/B ratio has a great influence on the compressive strength and the slump of UHPFRC. Based on the compressive strength and the fluidity of the UHPFRC, the optimum W/B ratio is 0.194 .

(3) When the total amount of cement and GGBFS is constant $\left(940 \mathrm{~kg} / \mathrm{m}^{3}\right)$, with the increase in the content ratio of GGBFS from $0 \%$ to $30 \%$, the compressive strength of UHPFRC decreases, while the fluidity increases. The optimal ratio of GGBFS-replaced cement is recommended as $20 \%\left(188 \mathrm{~kg} / \mathrm{m}^{3}\right)$.

(4) The dosage of FA can significantly improve the flowability of UHPFRC, and the influence of FA on compressive strength is not obvious. Results show that FA is suitable for replacing SF by $30 \%$ $\left(84.6 \mathrm{~kg} / \mathrm{m}^{3}\right)$ when the total amount of SF and FA is constant $\left(282 \mathrm{~kg} / \mathrm{m}^{3}\right)$.

(5) The particle size of sintered bauxite has a certain influence on the strength and fluidity of UHPFRC. The optimal ratio of $0-1 \mathrm{~mm}$ sintered bauxite to $1 \sim 3 \mathrm{~mm}$ sintered bauxite was recommended as $1.51: 1$.

\section{Data Availability}

The data used to support the findings of this study are available from the corresponding author upon request.

\section{Additional Points}

Highlights. (1) High strength and good workability of UHPFRC can be achieved under standard curing conditions. (2) The optimum W/B ratio is recommended as 0.194. (3) Fly ash can significantly improve the fluidity of UHPFRC. (4) The optimal ratio of $0-1 \mathrm{~mm}$ to $1 \sim 3 \mathrm{~mm}$ sintered bauxite is $1.51: 1$.

\section{Conflicts of Interest}

The authors declare that there are no conflicts of interest regarding the publication of this paper.

\section{Acknowledgments}

The authors would like to thank the National key R\&D Program of China (2016YFE0125600) and Program for Changjiang Scholars, Innovative Research Team in the University of Ministry of Education of China (IRT_16R67), National Natural Science Foundation of China (51508519), Outstanding Young Talent Research Fund of Zhengzhou University (1521322001), Key Scientific Research Projects of Henan Province for Colleges and Universities (14B560014 and 15A560040), and Industry-University-Research of Henan Province (162107000024).

\section{References}

[1] F. D. Larrard and T. Sedran, "Optimization of ultra-highperformance concrete by the use of a packing model," Cement and Concrete Research, vol. 24, no. 6, pp. 997-1009, 1994. 
[2] C. J. Shi, D. H. Wang, L. M. Wu, and Z. M. Wu, "The hydration and microstructure of ultra-high-strength concrete with cement-silica fume-slag binder," Cement and Concrete Composites, vol. 61, pp. 44-52, 2015.

[3] P. Richard and M. Cheyrezy, "Composition of reactive powder concretes," Cement and Concrete Research, vol. 25, no. 7, pp. 1501-1511, 1995.

[4] Y. W. Chan and S. H. Chu, "Effect of silica fume on steel fiber bond characteristics in reactive powder concrete," Cement and Concrete Research, vol. 34, no. 7, pp. 1167-1172, 2004.

[5] P. Zhang and Q. F. Li, "Durability of high performance concrete composites containing silica fume," Proceedings of the Institution of Mechanical Engineers, Part L: Journal of Materials: Design and Applications, vol. 227, no. 4, pp. 343349, 2013.

[6] D. P. Bentz and P. E. Stutzman, "Evolution of porosity and calcium hydroxide in laboratory concretes containing silica fume," Cement and Concrete Research, vol. 24, no. 6, pp. 1044-1050, 1994.

[7] P. Duan, Z. H. Shui, W. Chen, and C. H. Shen, "Effects of metakaolin, silica fume and slag on pore structure, interfacial transition zone and compressive strength of concrete," Construction and Building Materials, vol. 44, pp. 1-6, 2013.

[8] X. Zhang and J. Han, "The effect of ultra-fine admixture on the rheological property of cement paste," Cement and Concrete Research, vol. 30, no. 5, pp. 827-830, 2000.

[9] K. Wang and G. Zhi, Evaluating Properties of Blended Cements for Concrete Pavements: Final Report, Center for Portland Cement Concrete Pavement Technology, Iowa State University, Ames, IA, USA, 2003.

[10] H. Yazici, H. Yigiter, A. Karabulut, and B. Baradan, "Utilization of fly ash and ground granulated blast furnace slag as an alternative silica source in reactive powder concrete," Fuel, vol. 87, no. 12, pp. 2401-2407, 2008.

[11] P. Zhang, C. H. Liu, Q. F. Li, T. H. Zhang, and P. Wang, "Fracture properties of steel fiber reinforced high performance concrete containing nano- $\mathrm{SiO}_{2}$ and fly ash," Current Science, vol. 106, no. 7, pp. 980-987, 2014.

[12] P. Zhang, Y. N. Zhao, Q. F. Li, P. Wang, and T. H. Zhang, "Flexural toughness of steel fiber reinforced high performance concrete containing nano-SiO 2 and fly ash," Scientific World Journal, vol. 2014, Article ID 403743, 11 pages, 2014.

[13] H. Yazici, M. Y. Yardımcı, H. Yigiter, S. Aydın, and S. Türkel, "Mechanical properties of reactive powder concrete containing high volumes of ground granulated blast furnace slag," Cement Concrete Composites, vol. 32, no. 8, pp. 639-648, 2010.

[14] A. M. Neville, Properties of Concrete, Wiley, New York, NY, USA, 1996.

[15] S. Mindess, J. F. Young, and D. Darwin, Concrete, Prentice Hall, Upper Saddle River, NJ, USA, 2003.

[16] P. Zhang, Q. F. Li, and H. Y. Zhang, "Fracture properties of highperformance concrete containing fly ash," Proceedings of the Institution of Mechanical Engineers, Part L: Journal of Materials: Design and Applications, vol. 226, no. 2, pp. 170-176, 2012.

[17] H. W. Song and V. Saraswathy, "Studies on the corrosion resistance of reinforced steel in concrete with ground granulated blast-furnace slag-an overview," Journal of Hazardous Materials, vol. 138, no. 2, pp. 226-233, 2006.

[18] P. Richard and M. H. Cheyrezy, "Reactive powder concretes with high ductility and 200-800 MPa compressive strength," ACI Spring Conversion, vol. 144, pp. 507-518, 1994.

[19] H. Yigiter, S. Aydın, H. Yazici, and M. Y. Yardımcı, "Mechanical performance of low cement reactive powder concrete
(LCRPC)," Composites Part B: Engineering, vol. 43, no. 8, pp. 2907-2914, 2012.

[20] H. Yazıc1, M. Y. Yardımc1, S. Aydın, and A. S. Karabulut, "Mechanical properties of reactive powder concrete containing mineral admixtures under different curing regimes," Construction and Building Materials, vol. 23, no. 3, pp. 12231231, 2009.

[21] S. L. Yang, S. G. Millard, M. N. Soutsos, S. J. Barnett, and T. T. Le, "Influence of aggregate and curing regime on the mechanical properties of ultra-high performance fibre reinforced concrete (UHPFRC)," Construction and Building Materials, vol. 23, no. 6, pp. 2291-2298, 2009.

[22] P. N. Hiremath and S. C. Yaragal, "Effect of different curing regimes and durations on early strength development of reactive powder concrete," Construction and Building Materials, vol. 154, pp. 72-87, 2017.

[23] H. Yazici, "The effect of curing conditions on compressive strength of ultra high strength concrete with high volume mineral admixtures," Building and Environment, vol. 42, no. 5, pp. 2083-2089, 2007.

[24] P. R. Prem, B. H. Bharatkumar, and N. R. Iyer, "Influence of curing regimes on compressive strength of ultra high performance concrete," Sadhana, vol. 38, no. 6, pp. 1421-1431, 2013.

[25] H. S. Arel, "Effects of curing type, silica fume fineness, and fiber length on the mechanical properties and impact resistance of UHPFRC," Results in Physics, vol. 6, pp. 664-674, 2016.

[26] K. Wille, A. E. Naaman, S. El-Tawil, and G. J. Parra-Montesinos, "Ultra-high performance concrete and fiber reinforced concrete: achieving strength and ductility without heat curing," Materials and Structures, vol. 45, no. 3, pp. 309-324, 2011.

[27] Chinese National Standard, Common Portland Cement, GB 175-2007, Chinese National Standard, China, Beijing, 2007.

[28] Chinese National Standard, Fly Ash Used for Cement and Concrete, GB/T 1596-2005, Chinese National Standard, Beijing, China, 2005.

[29] Chinese National Standard, Reactive Powder Concrete, GB/T 31387-2015, Chinese National Standard, Beijing, China, 2015.

[30] Chinese National Standard, Standard for Test Method of Performance on Ordinary Fresh Concrete, GB/T 50080-2016, Chinese National Standard, Beijing, China, 2016. 


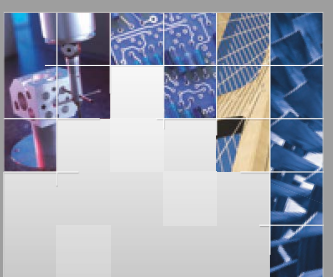

\section{Enfincering}
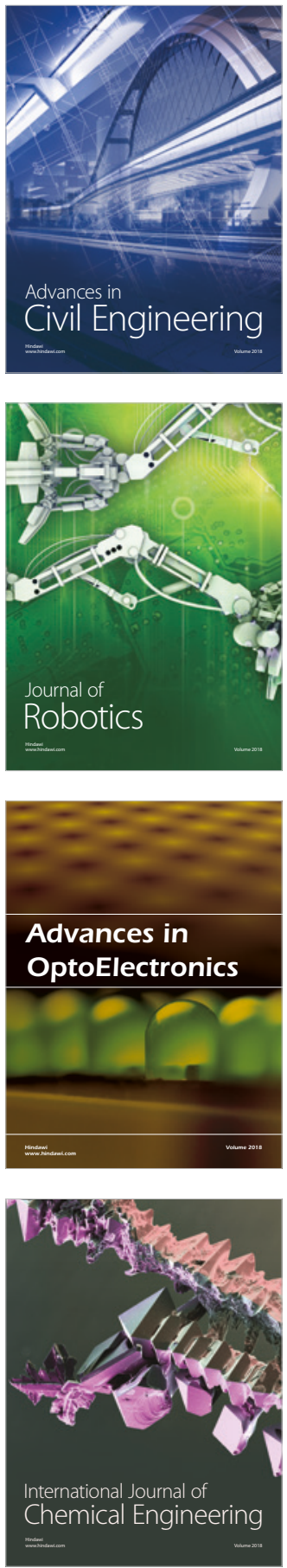

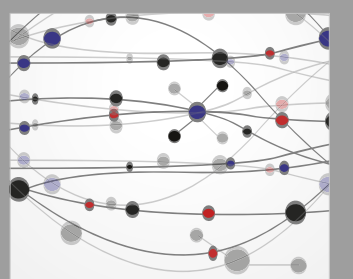

\section{Rotating \\ Machinery}

The Scientific World Journal

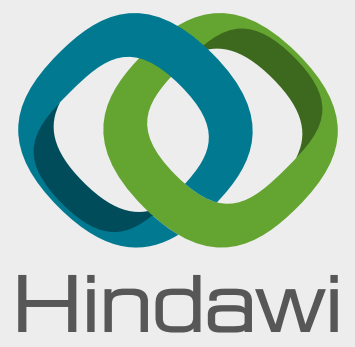

Submit your manuscripts at

www.hindawi.com
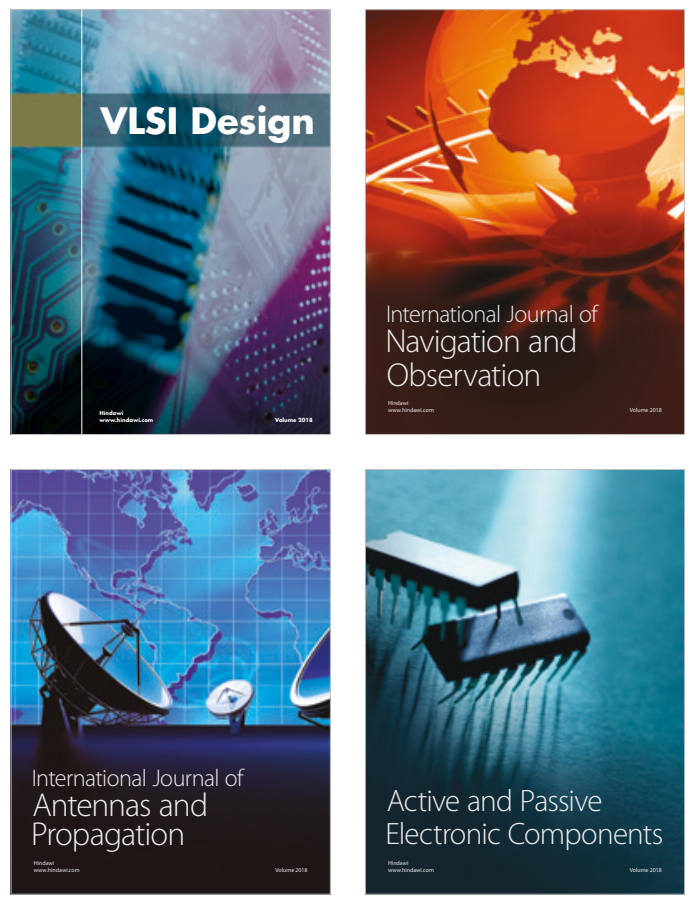
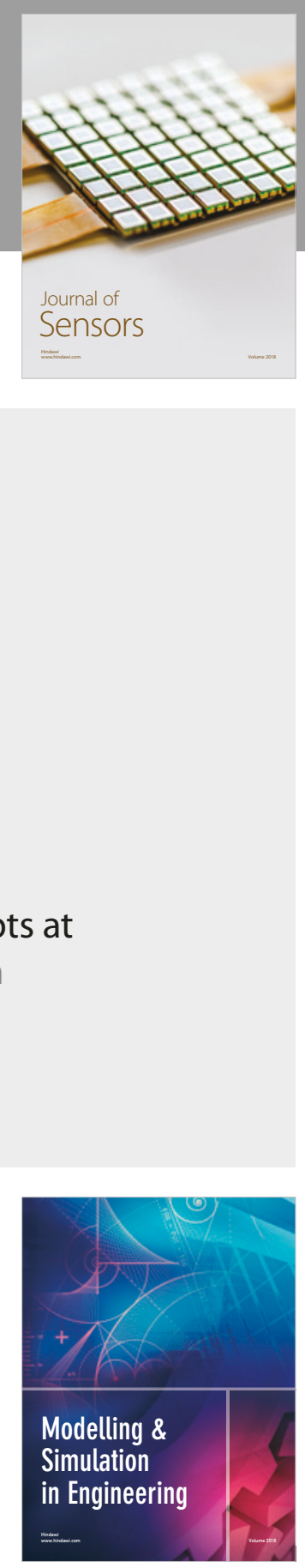

\section{Advances \\ Multimedia}
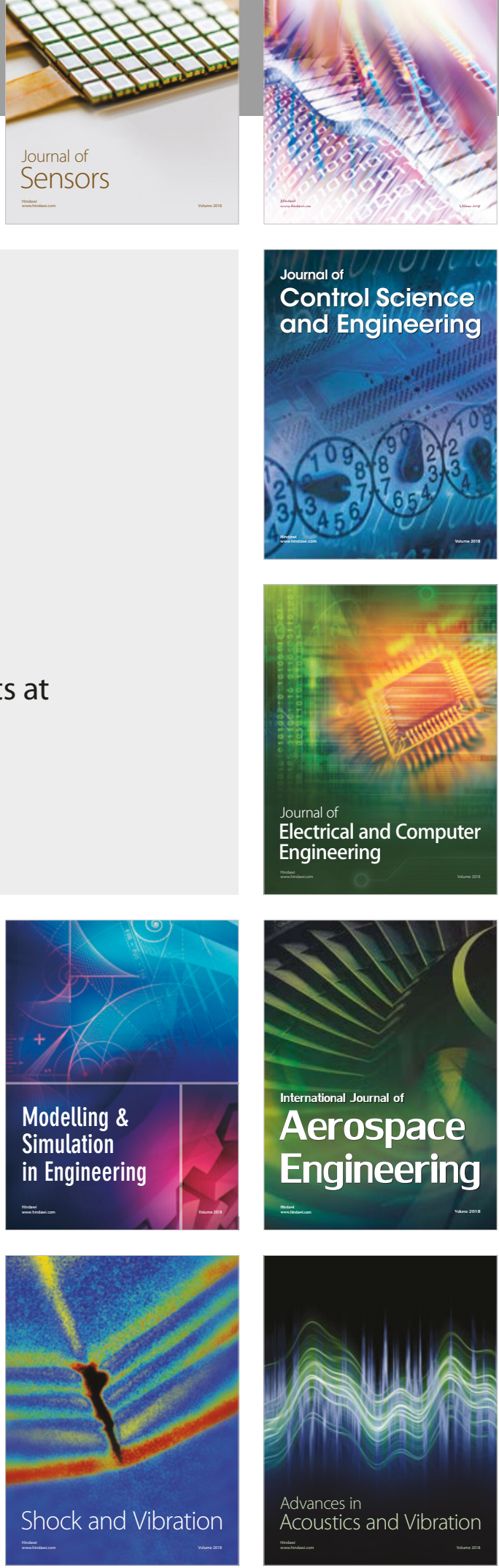